\title{
Cellular entry of nanoparticles via serum sensitive clathrin-mediated endocytosis, and plasma membrane permeabilization [Corrigendum]
}

Smith PJ, Giroud M, Wiggins HL, et al. Int J Nanomedicine. 2012;7:2045-2055.

Page 2054, Figure 11, the text "Average no of NPs in lumen: $\mathrm{N}_{f}=2.1 \times 10^{-3}$ " should read "Average no of NPs in lumen: $\mathrm{N}_{f}=2.1 \times 10^{-2}$, .

Page 2054, Figure 11, the figure legend "Figure 11 A series of calculations to estimate the number of nanoparticles that could enter a vesicle under the incubation conditions described in materials and methods. It is estimated that nanoparticles are nearly 25,000 times more likely to enter cells when they are bound to the membrane than in the fluid phase." should read "Figure 11 A series of calculations to estimate the number of nanoparticles that could enter a vesicle under the incubation conditions described in materials and methods. It is estimated that nanoparticles are nearly 2,500 times more likely to enter cells when they are bound to the membrane than in the fluid phase."

Page 2054, first column, line 13, the sentence "Even though the latter might be an overestimation, the current analyses suggest that under these conditions nanoparticles are nearly 25,000 times more likely to enter cells bound to the inner membrane of a vesicle than through the fluid phase." should read "Even though the latter might be an overestimation, the current analyses suggest that under these conditions nanoparticles are nearly 2,500 times more likely to enter cells bound to the inner membrane of a vesicle than through the fluid phase".
International Journal of Nanomedicine

\section{Publish your work in this journal}

The International Journal of Nanomedicine is an international, peerreviewed journal focusing on the application of nanotechnology in diagnostics, therapeutics, and drug delivery systems throughou the biomedical field. This journal is indexed on PubMed Central, MedLine, CAS, SciSearch ${ }^{\circledR}$, Current Contents ${ }^{\circledR} /$ Clinical Medicine,

\section{Dovepress}

Journal Citation Reports/Science Edition, EMBase, Scopus and the Elsevier Bibliographic databases. The manuscript management system is completely online and includes a very quick and fair peer-review system, which is all easy to use. Visit http://www.dovepress.com/ testimonials.php to read real quotes from published authors. 